\title{
A new permanent multi-parameter monitoring network in Central Asian high mountains - from measurements to data bases
}

\author{
T. Schöne ${ }^{1}$, C. Zech ${ }^{1}$, K. Unger-Shayesteh ${ }^{1}$, V. Rudenko ${ }^{1}$, H. Thoss ${ }^{1}$, H.-U. Wetzel ${ }^{1}$, A. Gafurov ${ }^{1}$, J. Illigner ${ }^{1}$, and \\ A. Zubovich ${ }^{2}$ \\ ${ }^{1}$ Helmholtz Centre Potsdam, GFZ German Research Centre for Geosciences, Potsdam, Germany \\ ${ }^{2}$ Central-Asian Institute of Applied Geosciences (CAIAG), Bishkek, Kyrgyzstan
}

Correspondence to: T. Schöne (tschoene@gfz-potsdam.de)

Received: 24 May 2012 - Published in Geosci. Instrum. Method. Data Syst. Discuss.: 22 June 2012

Revised: 3 January 2013 - Accepted: 18 January 2013 - Published: 19 February 2013

\begin{abstract}
Long-term monitoring of water resources and climate parameters at the scale of river basins requires networks of continuously operated in-situ stations. Since 2009, GFZ and CAIAG, in cooperation with the National Hydrometeorological Services (NHMS) of Central Asia, are establishing such a regional monitoring network in Kazakhstan, Kyrgyzstan, Tajikistan, Uzbekistan, and lately Afghanistan to collect observations of meteorological and hydrological parameters and to deliver them to the end-users for operational tasks and scientific studies. The newly developed and installed remotely operated multi-parameter stations (ROMPS) do not only monitor standard meteorological and hydrological parameters, but also deliver Global Navigation Satellite System (GNSS) data for atmospheric sounding as well as tectonic studies. Additionally, three stations integrate seismic sensors for earthquake monitoring. The observational data from the ROMPS is transmitted nominally in near-real time, but at least once a day to a centralized geo-database infrastructure for long-term storage and data redistribution. Users can access the data manually using a web-interface or automatically using SOS requests; in addition, data is planed to be distributed to the NHMS through standard communication and data exchange channels.
\end{abstract}

\section{Hydrometeorological monitoring in Central Asian headwaters - a technical challenge}

In the arid to semi-arid region of Central Asia (Fig. 1), water is a crucial resource both for the fresh water supply to the growing population as well as a necessary prerequisite for the economic development of the five former Soviet Republics in Central Asia - Kazakhstan, Kyrgyzstan, Tajikistan, Turkmenistan and Uzbekistan. All main rivers in Central Asia originate in the Central Asian high mountains and drain towards the low-land deserts and steppes often ending in endorheic lakes, such as the Aral Sea or Lake Balkhash. River runoff is formed mainly from the melt of seasonal snow pack and glacier ice in summer in the higher elevated parts of the river basins. The Central Asian headwaters cover an area of approximately $500000 \mathrm{~km}^{2}$ and are characterized by a pronounced relief reaching elevations of more than $7000 \mathrm{~m}$ a.s.l. and encompassing several orographic systems (e.g., Tien Shan, Pamir, Alai).

The role of the headwater catchments as the flow formation zone in Central Asia calls for a continuous monitoring of climate and water cycle parameters. Adequately spatially distributed ground-based monitoring stations are essential to capture the spatial variability of those parameters and are of utmost importance in water management, in particular for the operational task of the seasonal runoff forecast.

A major scientific question remains the impact of global climate change on the regional water resources. This question has been addressed by a number of recent studies mainly relying on historic data sets from selected climate stations (for an overview see: Sorg et al., 2012). However, researchers face a substantial lack of observations in the higher elevations (above $3000 \mathrm{~m}$ a.s.1.), where important water balance components such as glaciers and seasonal snow pack dominate, and hence the findings about changes in the flow formation zone remain highly uncertain. 


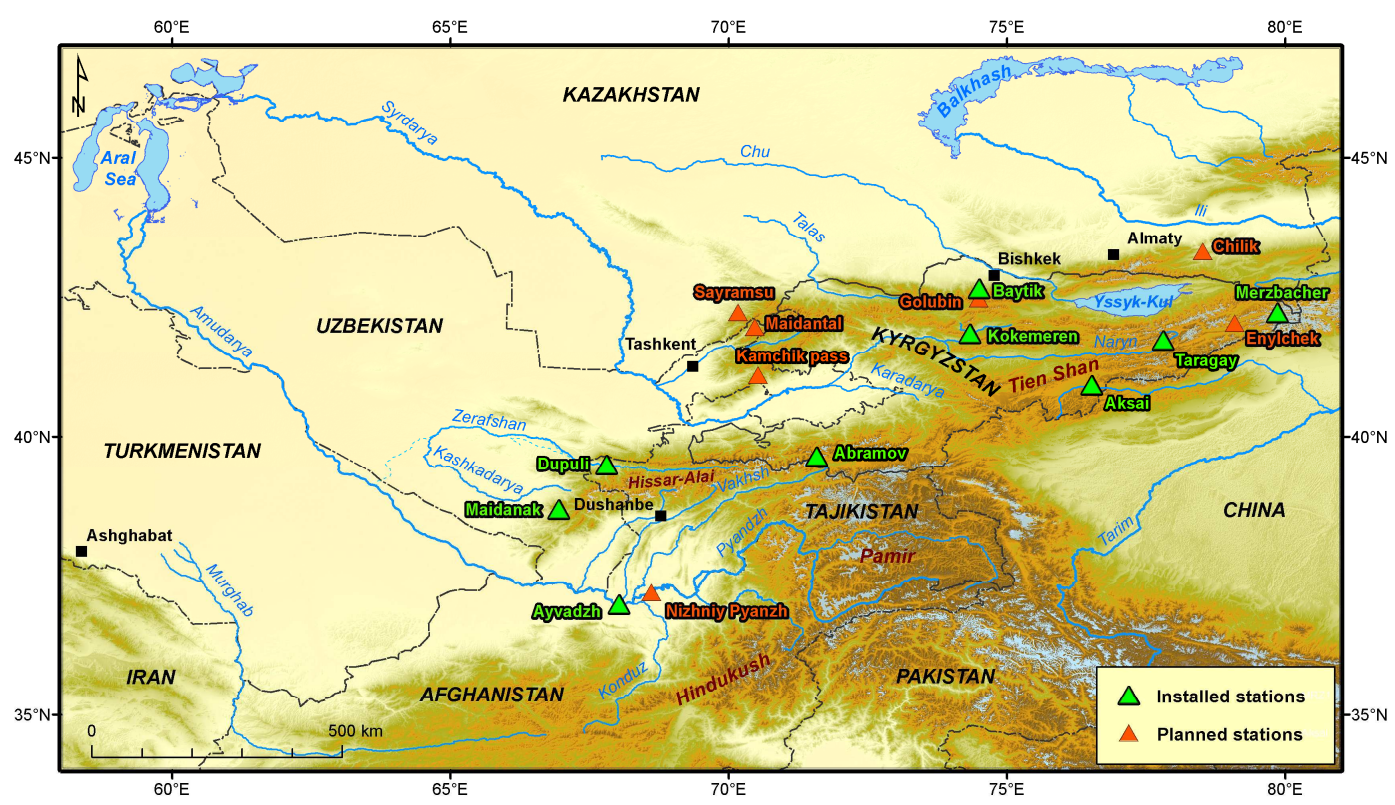

Fig. 1. The region of Central Asia (including northern Afghanistan) and the state of the ROMPS network by November, 2012.

In the past decades, hydrometeorological monitoring in Central Asia was largely based on manned outposts. Data was collected manually and sent by telephone or radio to centralized paper-based data management centers. After the collapse of the Soviet Union it became increasingly difficult for the new independent republics to maintain the existing monitoring network in Central Asia due to funding limitations. The resulting network decline primarily affected stations in the headwater catchments in altitudes above 2000 m a.s.l. (e.g., World Bank, 2009; Finaev, 2009). In Kyrgyzstan alone, the number of meteorological stations decreased from 83 stations in 1985 to 30 stations in 2000, the number of hydrological stations from 147 to 75 stations in the same period (Itibayev, 2009). This underpins the need for improvement of hydrometeorological monitoring in Central Asian headwater catchments. In the 1990s and 2000s, several internationally funded projects already addressed this issue and have succeeded to install a number of automatic monitoring stations; most prominent among them is the rehabilitated station at the Fedchenko glacier in the Pamir Mountains (Kayumov et al., 2002). Yet, there remain a number of challenges:

1. more stations are needed, especially at higher altitudes, to capture the variability of water cycle parameters in different parts of the orographic systems;

2. the additional stations need to be capable of reliable unmanned operation under the prevailing extreme environmental conditions in remote areas, have low maintenance requirements and, additionally, incur low operational costs at the same time;
3. near-real time or short-latency data transmission to data users is needed;

4. a data management infrastructure capable of facilitating data sharing among all countries of the region has to be implemented.

The four challenges are addressed in the frame of the CAWa project (www.cawa-project.net) and the "Global Change Observatory Central Asia (GCO-CA)" of the German Research Centre for Geosciences (GFZ) where German and CentralAsian scientists and specialists are establishing a regional hydrometeorological monitoring network of ROMPS with a special focus on the headwater catchments.

This paper is organized as follows: in Sect. 2 we present the ROMPS design and individual components including sensors, operation control facilities and communication lines. In Sect. 3, the data management unit (System Operation, Processing and Archiving Facility) is described. Section 4 demonstrates some examples of station implementations. Section 5 briefly reviews other monitoring network approaches. We finalize the paper with a discussion of the developed monitoring network approach.

\section{The ROMPS concept of the CAWa/GCO-CA network}

Against the background of degrading hydrometeorological monitoring networks in Central Asian headwater catchments, remotely operated multi-parameter stations (ROMPS) offer great opportunities to support a wide range of societal and scientific tasks, among them are weather observations and forecasts, long-term climate monitoring, river discharge monitoring and forecasts, crustal deformation and 


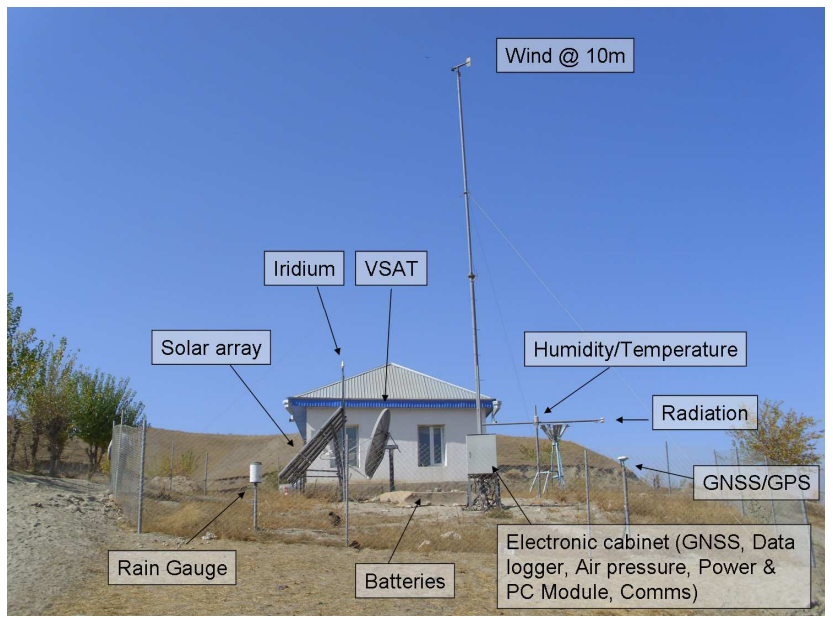

Fig. 2. CAWa station Dupuli (Tajikistan) with a typical sensor setup. The station is solar powered. Subsurface sensors are not shown.

earthquake monitoring as well as the establishment of waterrelated early warning systems. To serve those purposes, such stations have to combine different sensor types at one station and share power supply and communication devices while minimizing operational costs. The ROMPS concept (Fig. 2) presented in this section is based on the concept of GPScontrolled tide gauges which were developed as a component of the German-Indonesian Tsunami Early Warning System (Schöne et al., 2011).

\subsection{ROMPS concept and hardware}

The ROMPS integrate various sensors used in different geoscientific disciplines (Fig. 3). The general and open concept provides a ready platform to add sensors either by attaching the new hardware or by connecting external independent sensors through dedicated software components (e.g., seismometers using the SeisComP software, see Hanka et al., 2000).

Common to all ROMPS is a computer module (PC module) and a power module. The PC module consists of a lowvoltage embedded computer based on the PC/104 standard with extension cards and an $8 \mathrm{~GB}$ flash drive. The PC has a small Linux distribution installed to perform all station relevant tasks such as basic system operation, logging and storage of sensor data, data transfer via the satellite communication and system management and control (in particular, control of flash disk and power status). With a power consumption of 3 watts and an operating temperature ranging between $-60^{\circ} \mathrm{C}$ and $+50^{\circ} \mathrm{C}$, the $\mathrm{PC}$ module is suited for remote sites and extreme environmental conditions. The module also integrates a battery manager for managing several power lines that independently provide power to the sensors, data loggers and communication components. A keep-alive function to the PC module controlled by the battery manager

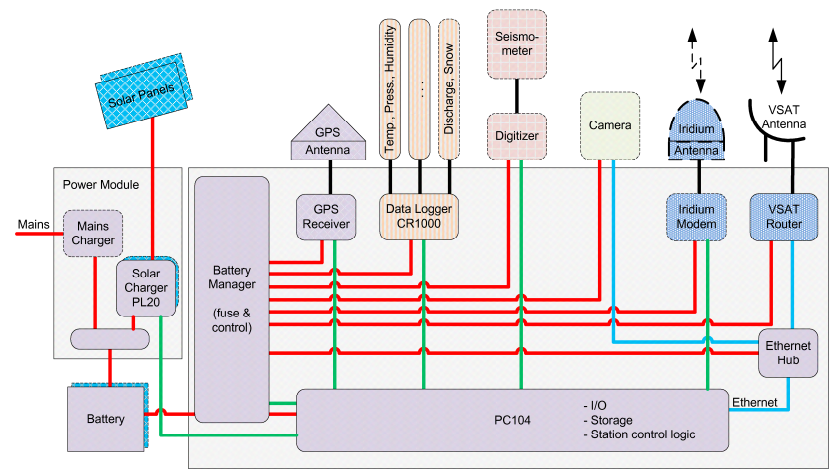

Fig. 3. Schematic ROMPS concept: (red lines) power lines, (green lines) RS232 connections, (blue lines) Ethernet connectors. The power module (left) provides $12 \mathrm{~V}$ power and power state information. All hardware is connected to and managed by the PC module (PC104 \& Battery manager) and dedicated software.

monitors the response time of the PC and, in case of failure, re-powers it.

The power module operates as a load balancer between up to three different external power sources, such as the solar arrays and a generator (if a local power line is available) and two independent battery circuits. The power module provides load and charge values accessible at a serial port interface to the PC and allows a dedicated power management. Depending on the current power level, hardware can be temporarily deactivated from the main system through the battery manager to preserve the base functionality of the ROMPS (see Sect. 2.3 and, e.g., Fig. 8b).

To provide sufficient power even during winter time with reduced daytime length, and during bad weather conditions (e.g., cloudy skies, fog, snow fall), up to six solar panels with each $520 \mathrm{Wh} \mathrm{d}^{-1}$ power and six batteries with $250 \mathrm{Ah}$ capacity each are installed. Permanent operation of the batteries is secured in a temperature range down to $-40^{\circ} \mathrm{C}$, while in extreme conditions they survive also a minimum temperature of $-60^{\circ} \mathrm{C}$.

The ROMPS are built in a control box with an IP66 grading which protects the electronic components from dust and humidity, and allows the installation without additional shelter. Sensors are connected outside the control box through pre-wired plugs. Thus, exchanging a sensor does not require opening the control cabinet. As an additional precaution, small packages of silica gel were usually placed within the control cabinet to absorb excessive moisture.

\subsection{Sensors}

The ROMPS are equipped with standard components meeting the official WMO requirements (WMO, 2008) which are extended by hydrological sensors, where appropriate. The connected hydrometeorological sensors (for details see Table 1) are operated by and their data is stored at a Campbell ${ }^{\circledR}$ 
Scientific Instruments CR1000 data recorder. As a standard common to all stations, the following sensors are integrated: wind sensor, combined air temperature and relative humidity probe, air pressure sensor, a tipping bucket for rain monitoring and a 4-component net radiation sensor to measure the ratio between the incoming short-wave and longwave infrared radiation versus surface-reflected short-wave and outgoing long-wave radiation. Optionally, up to eight soil moisture and soil temperature sensors complement the station setup. To support a broad range of applications, all sensors are sampled every $5 \mathrm{~min}$. The data is downloaded from the data recorder to the PC module and transferred preferably on an hourly basis by the satellite communication system to the System Operation, Processing and Archiving Facility (SOPAF) system (see Sect. 3) for further processing and distribution.

For wind measurements (speed, gust, direction) the RM Young (USA) wind monitor 05103, a propeller vane, is used in our ROMPS (e.g., Gorodetskaya et al., 2011; Maussion et al., 2011). Propeller vanes are more suitable for wind measurements in high mountain environments as they are better capable of coping with rime ice accumulation compared to cup anemometers (e.g., Box et al., 2004).

The tipping bucket rain sensor of RM Young (USA) is used for rain monitoring. In our installations the unheated version was selected, since solar-powered stations cannot deliver the necessary power for heating. After three years of operation the sensor is found to be sensitive to dust accumulation inside the sensor protection mesh, which is a drawback for long unattended operation. Also the tipping arm tends to be sensitive to strong alternating winds, in cases the sensor is not correctly anchored.

For air temperature and relative humidity, the combined sensors of the HMP series (Vaisala, Finland) are used. It is known that the measurements by such sensors especially of minimum and maximum temperatures are highly affected by the incoming and the reflected solar radiation, especially over high-albedo surfaces in snow-covered areas or on glaciers (e.g., Huwald et al., 2009). Hence, the selection of a radiation shield for sensor protection in high mountain environments is crucial (e.g., Box et al., 2004). For the ROMPS installations a naturally ventilated multi-plate cylindrical shield (Campbell 41003-5) is used. The humidity sensor gives values of relative humidity with respect to water. For temperatures below $0{ }^{\circ} \mathrm{C}$, the readings have to be corrected to give relative humidity with respect to ice (e.g., Reijmer et al., 2004; Anderson, 1994).

A four-component radiation sensor was chosen for the ROMPS because it gives consistent values for all individual radiation components, which is favorable compared to only net radiation or the use of two or more individual sensors each exhibiting different measurement uncertainties (Maussion et al., 2011). The selected NR01 sensor (Hukseflux, Netherlands) integrates two pyranometers for short-wave and two pyrgeometers for long-wave radiation measurements.
Due to power supply considerations the unheated version is used.

As a barometric sensor the Setra Barometric Pressure Transducer 278 (Setra, USA) was chosen. The sensor is available for different altitude ranges and different resolutions and shows sufficient long-term stability (Chard and Bugbee, 2006).

Soil water content is measured in different depths with the Campbell Soil Water Content Reflectometer CS616 (see the discussion in Mittelbach et al., 2012), while soil temperatures are measured with the Campbell Soil Temperature Sensor 107.

For headwater monitoring, information about snow height and snow properties as well as river discharge are crucial. Snow parameters are measured using a snow pack analyzing (SPA) system (Sommer, 2009) together with a temperaturecompensated ultrasonic snow depth sensor. The SPA consists of four flat-ribbon sensors (SPA-sensor) along which the complex impedance is measured at different frequencies. Based on the dielectric constants of the three components (ice, water and air) in the snow, the SPA-sensor derives information about the snow density and the liquid water and ice content of the snow pack. In combination with the snow depth sensor, the snow water equivalent is calculated. The SPA is sampled at 15 min intervals.

River discharge monitoring is performed using a RQ24 Doppler-based radar sensor (Sommer, 2008) measuring the surface velocity of the river water. In combination with a time-delay measurement (pulse radar), the water level height can be determined. The discharge can be calculated by the sensor if the system has been calibrated by integrating values for the river cross section area and the mean flow velocity. In the field, the solar-powered sensor is installed under bridges and provides water level and flow velocity data in a non-contact and failsafe way even under high discharge, flooding and turbulent flow regimes. A HF radio link connects the RQ24 system with the data recorder in the ROMPS main station. Data is taken every 5 min as part of the standard meteorological acquisition cycle.

Additionally, all ROMPS integrate a continuously operated geodetic Global Navigation Satellite System receiver (GNSS) providing $1 \mathrm{~Hz}$ sampling. The dense sampling is suitable for high-rate applications in dynamical deformation monitoring such as earthquake events. In most applications, however, only sub-sampled data (e.g., 30 s) is used, primarily to monitor tectonic plate movement and to derive precipitable water vapor (PWV) in the atmosphere. For this, SOPAF provides a GNSS processing functionality. GNSS phase observations are first converted to RINEX format (Gurtner and Estey, 2007) and then processed together with global GNSS station data from the International GNSS Service (IGS) (Dow et al., 2009) using the GAMIT software (Herring et al., 2009). From the processing results, the timevarying zenith wet delay is combined with information from meteorological sensors for estimating the PWV distribution 
Table 1. Primary hydrometeorological sensors used in the CAWa/GCO-CA network.

\begin{tabular}{|c|c|c|c|c|}
\hline Sensor & Manufacturer & Observed parameters & Accuracy & Sampling interval \\
\hline Wind Monitor 05103 & RM Young, USA & $\begin{array}{l}\text { Wind direction } \\
\text { Wind speed }\end{array}$ & $\begin{array}{l} \pm 3^{\circ} \\
\pm 0.3 \mathrm{~m} \mathrm{~s}^{-1}\end{array}$ & $5 \mathrm{~min}$ \\
\hline Tipping Bucket 52203 & RM Young, USA & Liquid precipitation & $\begin{array}{l}2 \% \mathrm{up} \text { to } \\
25 \mathrm{~mm} \mathrm{~h}^{-1} \\
3 \% \mathrm{up} \mathrm{to}^{50 \mathrm{~mm} \mathrm{~h}^{-1}}\end{array}$ & $5 \mathrm{~min}$ \\
\hline $\begin{array}{l}\text { HMP45C } \\
\text { Air temperature: } \\
1000 \text { ohm PRT } \\
\text { Relative Humidity: thin- } \\
\text { film capacitive polymer H } \\
\text { chip HUMICAP }{ }^{\circledR} 180\end{array}$ & Vaisala, Finland & $\begin{array}{l}\text { Air temperature } \\
\text { Relative humidity }\end{array}$ & $\begin{array}{l} \pm 2 \%(0 \% \\
\text { to } 90 \% \mathrm{RH}) \\
\pm 0.3^{\circ} \mathrm{C}(\text { at } \\
\left.0{ }^{\circ} \mathrm{C}\right)\end{array}$ & $5 \min$ \\
\hline Net Radiometer NR01 & Hukseflux, Netherlands & $\begin{array}{l}\text { Solar short-wave and far } \\
\text { infrared long-wave radia- } \\
\text { tion (incoming and } \\
\text { out-going) }\end{array}$ & $\begin{array}{l}\text { For daily } \\
\text { totals: } \pm 10 \%\end{array}$ & $5 \min$ \\
\hline $\begin{array}{l}\text { Barometric Pressure } \\
\text { Transducer } 278\end{array}$ & Setra, USA & Barometric air pressure & $\pm 1.2 \mathrm{hPa}$ & $5 \mathrm{~min}$ \\
\hline $\begin{array}{l}\text { Soil Water Content } \\
\text { Reflectometer CS616 }\end{array}$ & Campbell Scientific, UK & Volumetric water content & $\pm 2.5 \%$ & $5 \mathrm{~min}$ \\
\hline $\begin{array}{l}\text { Soil Temperature Sensor } \\
107\end{array}$ & Campbell Scientific, UK & Soil temperature & $\pm 0.2{ }^{\circ} \mathrm{C}$ & $5 \min$ \\
\hline Discharge System RQ-24 & Sommer, Austria & $\begin{array}{l}\text { Water level } \\
\text { River surface flow velocity } \\
\text { River discharge }\end{array}$ & $\begin{array}{l} \pm 2 \mathrm{~mm} \\
\pm 0.02 \mathrm{~m} \mathrm{~s}^{-1}\end{array}$ & $5 \mathrm{~min}$ \\
\hline $\begin{array}{l}\text { Snow Pack Analyzing } \\
\text { System (SPA) }\end{array}$ & Sommer, Austria & $\begin{array}{l}\text { Snow depth, snow density, } \\
\text { snow water equivalent, con- } \\
\text { tents of liquid water and ice }\end{array}$ & & $15 \mathrm{~min}$ \\
\hline
\end{tabular}

in the atmosphere (e.g., Bender et al., 2008). The derived PWV values are stored in a standard IGS time interval of $5 \mathrm{~min}$ and are made accessible through SOPAF (Sect. 3).

Optionally, seismological sensors (broadband and/or strong motion sensors) can be connected to and completely handled by the station. The seismic data is then delivered to the international GEOFON network in real-time using the SeisComP software (Hanka et al., 2000) through the VSAT communication system.

At some ROMPS also automated digital optical cameras are integrated. They are used for the estimation of glacier mass balances by continuously monitoring the snow line and the percentage of snow coverage on the glacier (Corripio, 2004; Rabatel et al., 2005). In addition, the pictures allow for the validation of selected hydrometeorological measurements, such as snow availability. The pictures taken by the cameras are stored on the station's PC and transmitted to SOPAF for further distribution. Good experience has been gained with the Mobotix M24M camera (Mobotix, Germany). Lenses are selected to best cover the observation area.

\subsection{Station operation and software}

All ROMPS are operated and managed by several software components and scripts (Fig. 4) running on the PC module (see Sect. 2.1). Based on the Linux operating system, several $\mathrm{sh} / \mathrm{csh}$ and perl scripts have been developed to provide the basic functionality, e.g., for the watchdog function, data communication, backups, malfunction recovery and the disk management. Additionally, each attached hardware device (e.g., GNSS or Campbell data recorder) is operated by using dedicated C-based software applications. The software modules manage the hardware by collecting and storing data at predefined intervals and provide house-keeping data and self-test capabilities.

The power management is provided by the battery manager as part of the PC module. The power lines can be 


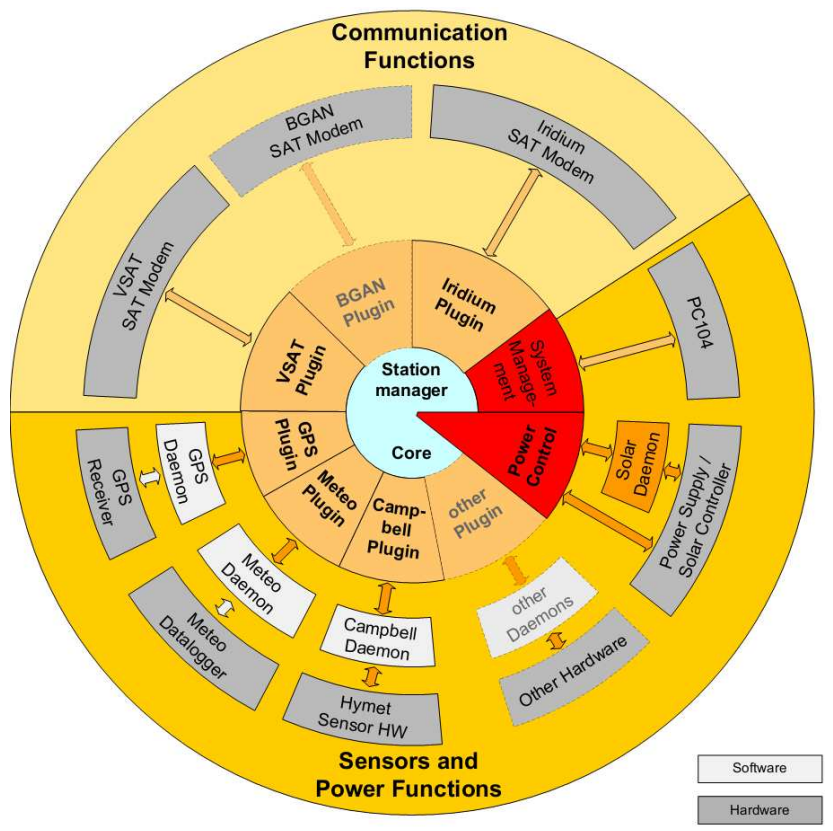

Fig. 4. ROMPS Software concept for the station management. Other hardware and daemons (gray letters) can be integrated. Modified after Kloth (2008).

switched on by software applications, if sufficient power is available. If the power drops below the individually defined thresholds, the hardware is switched off automatically until power recovery. With the managing software taking care for those limits, the station's hardware can be operated with minimal interruptions. Due to the effective power management design the only hardware device occasionally affected by power limitations is the VSAT communication system with its $4 \mathrm{~A}$ power consumption. Thus, especially in winter time, the VSAT communication may be terminated temporarily by the control of the battery manager.

Station self-timing is achieved by using the time information from the GNSS receiver. On an hourly basis, the station clock is synchronized. Consequently, all software modules use the computer clock for timing their data readings.

Beside the actual sensor readings, also status information about the ROMPS operation (e.g., battery voltage, load, power usage) is acquired and transmitted by default. This allows for performance and failure analysis of the ROMPS, which is of prime importance in remote deployments of sensor networks (Ingelrest et al., 2010).

\subsection{Data communication}

Permanent monitoring sites require independent, stable and cost-effective communication lines. For urban areas, a multitude of communication techniques exist, including local area networks (LAN) or the general packet radio service (GPRS). In remote areas, satellite-based communication provides the only reliable site access. Some remote installations use one-
Table 2. Operational characteristics of satellite-based two-way communication systems (for power consumption, bandwidth and cost ratio).

\begin{tabular}{lrrl}
\hline & $\begin{array}{r}\text { Power Consumption } \\
\text { @ 12 V transmit/ } \\
\text { receive/stand-by (A) }\end{array}$ & $\begin{array}{r}\text { Bandwidth } \\
\text { (Kbps) }\end{array}$ & $\begin{array}{l}\text { Bandwidth/ } \\
\text { Cost ratio }\end{array}$ \\
\hline VSAT & $\sim 4 / \sim 4 / \sim 4$ & $>30$ (scalable) & high \\
BGAN & $\sim 1 / \sim 1 / \sim 0.5$ & $>150$ & low \\
Iridium & $0.45 / 0.24 / 0.12$ & 0.3 & very low \\
\hline
\end{tabular}

way communication only, e.g., through the GTS system (EUMETSAT, 2009), ARGOS (ARGOS, 2011) or meteor burst communication technology (Schilling, 1993), as a reliable and cost-effective but low-bandwidth system. On the other hand, multi-sensor stations like ROMPS with their different types of data streams require higher bandwidth, real-time access and a two-way communication lines. Only few systems are meeting those requirements, among them very small aperture terminals (VSAT) (e.g., Angermann et al., 2010), Inmarsat's Broad Band Global Area Network (BGAN) system (Inmarsat, 2009) and low-bandwidth satellite-based communication systems like IRIDIUM (Iridium, 2010).

For the long-term operation of permanent monitoring systems, communication costs are essentially contributing to the total operational costs. Hence, for the selection of the main communication system, total costs (i.e., the combination of the initial investment, depreciation and effective annual costs for bandwidth) have to be considered. Table 2 gives an overview on the characteristics of three satellitebased two-way communication systems.

An important aspect in the communication design is the acceptable latency of data transmission and the data volume. For the hydrometeorological variables data transmission every three (or six) hours are sufficient to meet the current WMO requirements for synoptic weather observations. However, the ROMPS concept integrates different sensor components which benefit from real-time and near realtime access (e.g., seismometers for earthquake monitoring, real-time GNSS networks). Here, broadband communication provides a significant advantage for those sensors groups. For potential future applications, e.g., in early warning systems for meteorological hazards, flooding or glacier lake outbursts (GLOF) monitoring, the stations also benefit from near real-time data transmission.

For the CAWa/GCO-CA network in Central Asia, VSAT was chosen as the primary communication tool. Especially the scalable bandwidth and high bandwidth/cost ratio make long-term operation sustainable. Since all stations use a bundled bandwidth, partner organizations in the different Central Asian countries do not need individual service provider contracts. All installations use the iDirect 3000 Series Satellite Router with a $\emptyset 1.8 \mathrm{~m}$ Prodelin Ku-band antenna. Data access 
is established via the EXPRESS AM22 satellite to a central hub.

As shown before, VSAT installations are demanding in terms of power consumption. Nonetheless, the experience with several ROMPS installed in Central Asia showed that even for high-mountain installations with sometimes limited sun exposure, the stations can be operated $24 \mathrm{~h}$ a day with a minimum of two hours of daily communication access. In summer periods, up to $24 \mathrm{~h}$ of data access is usually possible.

As a redundant communication line an IRIDIUM SCV$\mathrm{X}$ modem is integrated into the stations. Due to the low bandwidth and high per-minute charge, this modem is only used for backup and as a backdoor for basic system operation while VSAT is used to continuously transmit the data to SOPAF.

\section{System Operation, Processing and Archiving Facility (SOPAF)}

The System Operation, Processing and Archiving Facility (SOPAF) is the central IT-platform of the CAWa monitoring network and serves to collect, process, and archive all information delivered by the ROMPS. As such it integrates information obtained from heterogeneous information resources as well as to support the integration of various data types such as meteorological, hydrological, GNSS or seismic data. It also provides dissemination functions for the observations and processing results to different user groups via web-based services. Therefore, SOPAF must meet the following requirements:

- the ability to interact and communicate with different types of resources (sensor stations, virtual sensor networks, processed data);

- the ability to add new stations, new types of sensors as well as copies of existing sensor types or processing results;

- allow access to the data (display and download functions) for external users using standard Internet browsers, HTTP-requests or applications running in Java Web Start;

- the ability to communicate with existing monitoring networks (e.g., those operated by the national Hydrometeorological Services) using standard exchange protocols. This requirement enables users to easily integrate requests to SOPAF into their operational standard procedures. For data exchange common formats are used, e.g., CREX (ECMWF, 2006) and KN01 (a format widely used in the former Soviet Union, and today, in many Central Asian countries);

- the portability to different operating systems. To achieve a maximum independence from operating systems,
JAVA was selected as the programming language. In addition, Java Enterprise Edition platform provides already tools to access the system via common Internet protocols (e.g., http);

- support the re-use of software components in client applications. An Open Standard Interface including software for developers of special applications should be provided.

Observational networks are tending to be or to become inhomogeneous over time in their used data formats, the data transfer protocols and/or the used communication lines. In order to be able to adapt to these changes in the long-term, SOPAF's implementation is based on the standards of the Sensor Web Enablement (SWE) initiative (Chu et al., 2006) of the Open GIS Consortium (OGC, 2010) that defines standardized service interfaces for the access to sensor data and networks. SWE completely hides the heterogeneity of the sensor network to the user and simplifies the access to the data. SOPAF is built on the basis of the Tsunami Service Bus (TSB) (Fleischer et al., 2010). As the TSB, SOPAF is acting as an integration platform providing interfaces and services for the access to sensor data following the SWE standards like the Sensor Observation Service (SOS) (SOS, 2007).

\subsection{Information model for measurements}

The SOPAF internal data model is based on the SWE Observation and Measurement specification (O\&M, 2010) in combination with the SOS standard data model (SOS, 2007) consisting of the following objects: FeatureOfInterest, $\mathrm{Ob}$ servation, Phenomenon, CompositePhenomenon, Procedure, and Offering. To integrate the observations from the "physical world" into the "abstract world" of the SWE standard, a mapping is necessary (Table 3 ). To ensure an easy access to the data for end users from different disciplines the overall information is organized by certain Offerings. For example, current Offerings are "meteorology", "hydrology", "seismology", or "GPS measurements". Based on WMO standards (WMO, 2008), meteorological and hydrological parameters being physically related to each other are grouped as CompositePhenomenon, e.g., "Temperature, Pressure, Humidity", "Surface wind", "Precipitation" "Radiation", or "Soil Moisture".

\subsection{Interfaces to SOPAF - user interaction}

As outlined in Sect. 2.2, the installed ROMPS measure or derive a wide range of currently about 100 meteorological, hydrological and geophysical parameters, a number which might easily be expanded in the future.

In order to provide convenient access to the measured parameter sets, SOPAF offers two levels of interfaces, (1) a web service and (2) a graphical user interface (GUI). For the public web interface service SOPAF implements three 
Table 3. Relationship between SWE definitions and their mapping to SOPAF components.

\begin{tabular}{|c|c|c|}
\hline SOS object name & Object description & Corresponding names in SOPAF \\
\hline FeatureOfInterest & $\begin{array}{l}\text { Geo-referencing of the } \\
\text { sensor, assignment to } \\
\text { the location of the } \\
\text { Observation }\end{array}$ & $\begin{array}{l}\text { Abramov Station } \\
\text { Baitik Station } \\
\text { Taragay Station } \\
\text {.. }\end{array}$ \\
\hline Procedure & $\begin{array}{l}\text { Creates the type of Observation (Phenomenon) } \\
\text { by a sensor, simulation product or processing } \\
\text { results (in SOPAF FeatureOfInterest is } \\
\text { identically used to Procedure) }\end{array}$ & $\begin{array}{l}\text { Abramov Station } \\
\text { Baitik Station } \\
\text { Taragay Station } \\
\ldots\end{array}$ \\
\hline Observation & $\begin{array}{l}\text { Measured value created by a sensor } \\
\text { related to a distinct time or period }\end{array}$ & \\
\hline Phenomenon & $\begin{array}{l}\text { Type of an Observation (e.g., air temperature, } \\
\text { wind speed, rain), related to the FeatureOfInterest }\end{array}$ & see Table 4 \\
\hline CompositePhenomenon & $\begin{array}{l}\text { Grouping of several physically related phenomena } \\
\text { (Phenomenon) (e.g., CompositePhenomenon "Surface } \\
\text { wind" is composed of phenomena (Phenomenon) wind } \\
\text { speed, gust and wind direction) }\end{array}$ & $\begin{array}{l}\text { Temperature, Pressure, Humidity } \\
\text { Station Operation } \\
\text { U10 wind } \\
\text { Radiation } \\
\text { Soil Parameters } \\
\text { Precipitation: Rain, Snow } \\
\text { River Discharge } \\
\text { Snow Cover Parameters } \\
\ldots\end{array}$ \\
\hline Offering & $\begin{array}{l}\text { Group of Observation(s) offered by a service } \\
\text { (e.g., web site) to the user }\end{array}$ & $\begin{array}{l}\text { Meteorology } \\
\text { Hydrology } \\
\text { Station Operation } \\
\text { All Phenomena } \\
\text { GPS measurements }\end{array}$ \\
\hline
\end{tabular}

core operations which correspond to the "core profile" set of operations as defined by the SOS: GetCapabilities, GetObservation and DescribeSensor. The function GetCapabilities is used to acquire meta-information about the content of the data base system or of an individual sensor. Based on this information, GetObservation queries specific information on the measured physical values. The request $D e$ scribeSensor is used to provide all meta-information about a particular sensor. To assist user specific developments a web-based "SOS Test client" has been implemented (http: //cawa.gfz-potsdam.de:8080/SOS/, see Fig. 5) providing examples of all three functions in XML format.

For those users who do not wish to directly integrate SOS requests to SOPAF into their information systems, a graphical user interfaces (GUI) can be used to extract information from SOPAF and to export data into e.g., commaseparated value (CSV) files (http://cawa.gfz-potsdam.de: 8080/Availability/, see Fig. 6).

\subsection{IT Infrastructure and implementation}

SOPAF collects all observations from the CAWa and GCOCA hydrometeorological network and serves as the main point for data access. It is also able to integrate data provided by other data services, e.g., from the National Hydrometeorological Services). A generalized diagram of the interaction between individual SOPAF components is outlined in Fig. 7.

Through the satellite communication, formatted or binary data is uploaded by FTP from the ROMPS to two centralized servers at CAIAG in Bishkek, Kyrgyzstan, or to GFZ in Potsdam, Germany. Several parallel-operating retrievers are configured for the different sensor types and for dedicated file types. After file arrivals the retriever sends the station data to the dispatcher which translates and writes the proprietary formatted information into the SOPAF data model.

As hardware infrastructure, SOPAF uses two independent but identical Sun Fire X4600 servers increase the access availability and to allow a faster data access in both from Central Asia and the world. The base operating system of the computers is NOVELL SUSE Linux Enterprise 11, which controls Ubuntu 10.04 in virtual machines. For the realization of the SOPAF system, the JAVA EE technology ${ }^{1}$,

\footnotetext{
1 http://www.oracle.com/technetwork/java/javaee/tech/index. html
} 


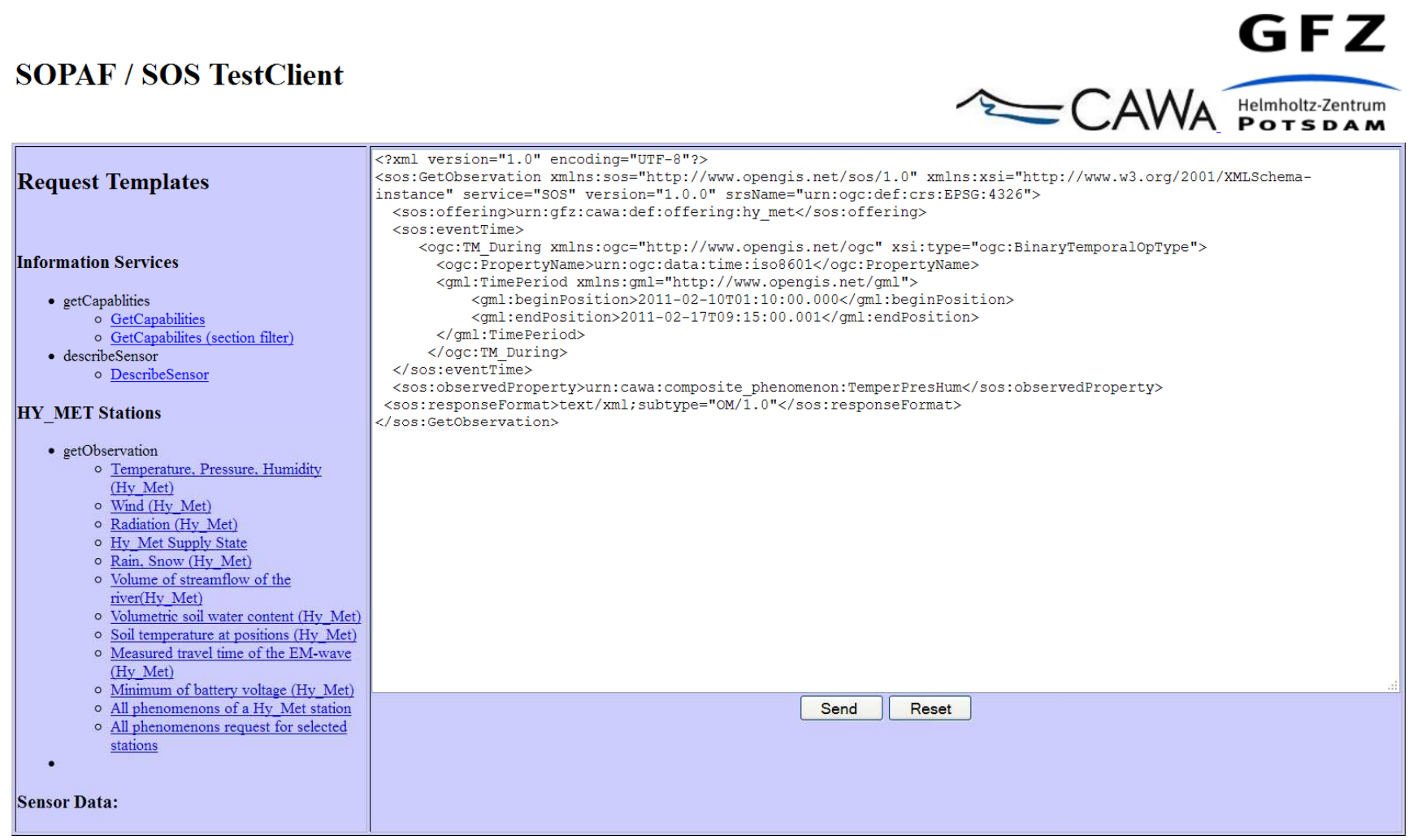

Fig. 5. The SOS Test client, which is designed for writing queries in XML format, contains sample code to support user applications.

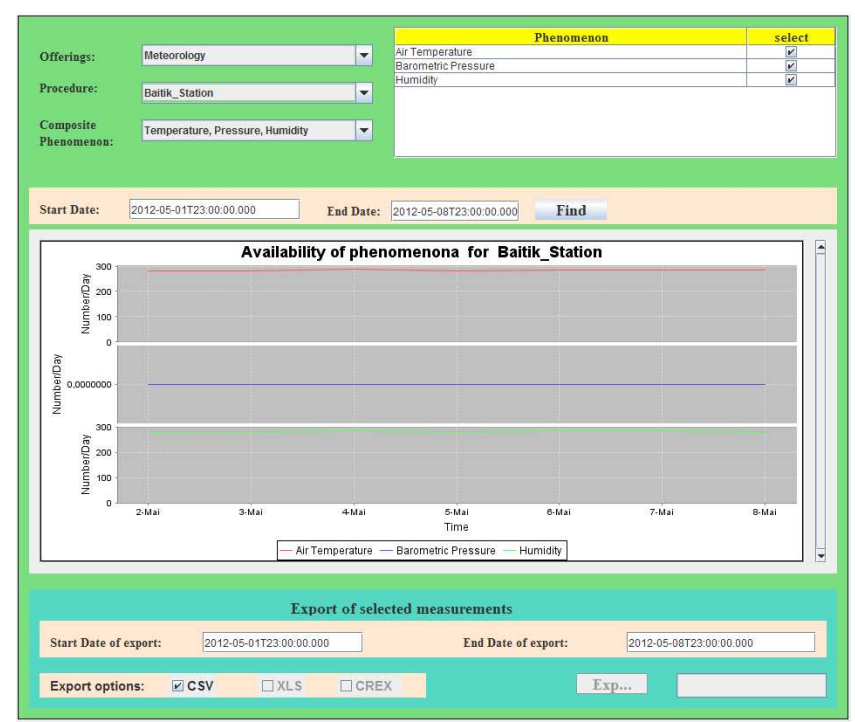

Fig. 6. Export of information from SOPAF. Graphical user interface (GUI) for users who prefer the data in the formats CSV (and in future also XLS or CREX).
Enterprise JavaBeans ${ }^{2}$, JavaServer Faces Technology (JSF) ${ }^{3}$, Java Message Service (JMS) ${ }^{4}$ and the Extensible Markup Language (XML) were chosen as developing tools. The data model is implemented in the object-relational database management system PostgreSQL (www.postgresql.org) Version 8.4. The application server JBoss Version 4.2.3 (www. jboss.org) manages all software components of SOPAF.

\section{CAWa and GCO-CA monitoring network}

A map of the current and planned station locations is shown in Fig. 1. The network design focuses mainly on the higher elevations where the recent decline of monitoring stations and networks established in Soviet times was strongest, and the resulting observational gap hinders research on climate and hydrological change as well as operational tasks in water management such as the seasonal runoff forecast.

All stations have an identical set of meteorological sensors and only a few different types of geodetic GPS receiver

\footnotetext{
2 http://www.oracle.com/technetwork/java/javase/tech/ index-jsp-138795.html

3 http://www.oracle.com/technetwork/java/javaee/ javaserverfaces-139869.html

${ }^{4}$ http://www.oracle.com/technetwork/java/jms/index.html
} 
Table 4. CompositePhenomenon defined by combining SOPAFPhenomenon. The SOS construct of CompositePhenomenon (SOS, 2007) gives users a more convenient access to observed quantities, which are physically closely related. The table shows only a subset of defined CompositePhenomenon, the full set is available by methods described in Sect. 3.2.

\begin{tabular}{ll}
\hline CompositePhenomenon & Phenomenon \\
\hline Temperature, & Air Temperature \\
Pressure, & Humidity \\
Humidity & Barometric Pressure \\
\hline \multirow{3}{*}{ Surface wind } & Wind Speed (max) \\
& Wind Speed \\
& Wind Direction \\
\hline \multirow{3}{*}{ Radiation } & Outgoing (reflected) long-wave \\
& solar radiation \\
& Net short-wave solar radiation \\
& Albedo \\
& Incoming short-wave solar radiation \\
& $\ldots$ \\
\hline \multirow{2}{*}{ Precipitation } & Average Snow Height \\
& Rain/Hail \\
\hline & River Discharge \\
Stream Flow & River water level \\
& River flow velocity \\
\hline
\end{tabular}

(Table 5). Additionally, some stations have site specific installations of snow measuring systems or river discharge sensors. This set of sensors from a limited number of manufacturers simplifies the station management and requires only minimal resources for maintenance. Table 6 gives the names and locations of stations planned for installations in 2013 and 2014. Two exemplary stations are described in more detail.

\subsection{Station Taragay}

Since 2010, Taragay station is monitoring hydrometeorological parameters in the Naryn catchment. There has been a predecessor station operated by CAIAG equipped with continuous GPS, a broadband seismometer and a compact meteorological sensor. While the GPS and seismometer are continuously used in the new station, the compact meteorological sensor was replaced by the standard meteorological equipment (see Table 1). The data is transmitted by a VSAT connection to SOPAF. The seismometer which is contributing to the GEOFON network (Hanka et al., 2000) is operated by the ROMPS station computer and shares the bandwidth of the VSAT link.

This station perfectly demonstrates the availability and limitations of the data connection in terms of seasonal variations in sunshine duration. Due to the high power consumption of the VSAT, data communication is continuously operated during summer time only when the solar input is

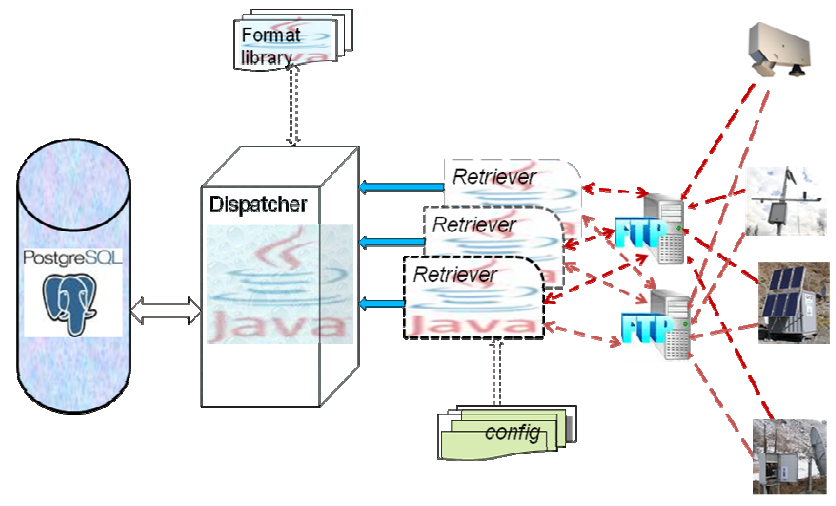

Fig. 7. SOPAF - collection and processing of information. The retrievers are forwarding the newly arrived data. The dispatcher converts the information into the SOS data model using the translation information of the format-library.

available for 8 to $14 \mathrm{~h}$. Between late autumn and early spring the on-time is reduced to a few hours daily, depending on the solar input. Figure 8a shows the power balance (charge versus load, VSAT on-times, time of positive power balance) and Fig. $8 \mathrm{~b}$ compares the power supply for the summer and winter solstice.

\subsection{Station Abramov glacier}

The Abramov glacier is located in the Alai range in Southern Kyrgyzstan draining towards the Vaksh river. Between 1967 and 1999 a permanent glacier observatory adjacent to the glacier had been operated by the Central Asian Research Institute for Hydrometeorology (SANIGMI) in Tashkent. The data of this period is published in Pertziger (1996). In 1999, the station was vandalized and destroyed. The main research of the former station was focused on continuous glaciological, hydrological and meteorological measurements. In August 2012, a ROMPS was installed close by. Logistical constraints and site security issues had required a slight re-location of the new automated station to a higher position. The suite of sensors comprises standard meteorological equipment (see Tables 2 and 5). In addition, two surveillance cameras, installed by the World Glacier Monitoring Service (WGMS, www.wgms.ch) and connected to the base station by a LAN cable (camera \#1) and a radio modem (camera \#2), are monitoring most of the snow accumulation and ablation area and the glacier tongue twice a day with one hour offset between the shots (Fig. 9). Based on the analysis of these frequent camera pictures in combination with ablation stake readings, glacier mass balance studies can be carried out (e.g., Rabatel et al., 2005, 2008; Jeanicke et al., 2006; Huss et al., 2012). The installed SPA (Sommer, 2009) delivers information about the accumulated snow and its properties (e.g., water and ice content, snow density, water equivalent). This combination will allow the prediction of the onset 
Table 5. Overview about the installed ROMPS and their sensor equipment (status November 2012). The seismometer at Kokomeren is independently installed sharing the VSAT link only. The distance in brackets for the river discharge is the horizontal distance between the main station and the discharge sensor.

\begin{tabular}{|c|c|c|c|c|c|c|c|c|c|}
\hline & Baitik & Taragay & Kokomeren & Abramov & Merzbacher $1 \& 2$ & Dupuli & Ayvadzh & Aksai & Maidanak \\
\hline Coordinates & $\begin{array}{l}42^{\circ} 39 \mathrm{~N}, \\
74^{\circ} 30^{\prime} \mathrm{E}\end{array}$ & $\begin{array}{l}41^{\circ} 44^{\prime} \mathrm{N} \\
77^{\circ} 48^{\prime} \mathrm{E}\end{array}$ & $\begin{array}{l}41^{\circ} 51^{\prime} \mathrm{N} \\
74^{\circ} 20^{\prime} \mathrm{E}\end{array}$ & $\begin{array}{l}39^{\circ} 39^{\prime} \mathrm{N} \\
71^{\circ} 35^{\prime} \mathrm{E}\end{array}$ & $\begin{array}{l}42^{\circ} 13^{\prime} \mathrm{N} \\
79^{\circ} 51^{\prime} \mathrm{E}\end{array}$ & $\begin{array}{c}39^{\circ} 29^{\prime} \mathrm{N} \\
67^{\circ} 48^{\prime} \mathrm{E}\end{array}$ & $\begin{array}{c}36^{\circ} 59^{\prime} \mathrm{N} \\
68^{\circ} 01^{\prime} \mathrm{E}\end{array}$ & $\begin{array}{c}40^{\circ} 55^{\prime} \mathrm{N} \\
76^{\circ} 31^{\prime} \mathrm{E}\end{array}$ & $\begin{array}{c}38^{\circ} 40^{\prime} \mathrm{N} \\
66^{\circ} 54^{\prime} \mathrm{E}\end{array}$ \\
\hline Altitude & $1580 \mathrm{~m}$ & $3510 \mathrm{~m}$ & $1470 \mathrm{~m}$ & $4100 \mathrm{~m}$ & $3400 \mathrm{~m}$ & $1060 \mathrm{~m}$ & $320 \mathrm{~m}$ & $3050 \mathrm{~m}$ & $2580 \mathrm{~m}$ \\
\hline River basin & Chu & Naryn & Naryn & Vaksh & Aksu & Zerafshan & Amudarya & Naryn & Kashkadarya \\
\hline Installation & Dec. 2009 & Aug. 2010 & Nov. 2010 & Aug. 2011 & Aug. 2009 & May 2012 & May 2012 & Aug. 2012 & Nov. 2012 \\
\hline \multicolumn{10}{|l|}{ Sensors } \\
\hline GPS receiver & $\mathrm{X}$ & $\mathrm{X}$ & $\mathrm{X}$ & $\mathrm{X}$ & $\mathrm{X}$ & $\mathrm{X}$ & $\mathrm{X}$ & $\mathrm{X}$ & $\mathrm{X}$ \\
\hline Seismometer & & $\mathrm{X}$ & $(\mathrm{X})$ & planned & $X$ & & & $\mathrm{X}$ & \\
\hline Wind & $\mathrm{X}$ & $\mathrm{X}$ & $\mathrm{X}$ & $\mathrm{X}$ & $\mathrm{X}$ & $\mathrm{X}$ & $X$ & $X$ & $\mathrm{X}$ \\
\hline Air pressure/humidity & $\mathrm{X}$ & $\mathrm{X}$ & $\mathrm{X}$ & $\mathrm{X}$ & $\mathrm{X}$ & $\mathrm{X}$ & $\mathrm{X}$ & $\mathrm{X}$ & $\mathrm{X}$ \\
\hline 4-components net radiation & $\mathrm{X}$ & $\mathrm{X}$ & $\mathrm{X}$ & $\mathrm{X}$ & $\mathrm{X}$ & $\mathrm{X}$ & $X$ & $X$ & $\mathrm{X}$ \\
\hline Soil moisture \& Soil temperature & $\mathrm{X}$ & $\mathrm{X}$ & $\mathrm{X}$ & $\mathrm{X}$ & $\mathrm{X}$ & $\mathrm{X}$ & $\mathrm{X}$ & $\mathrm{X}$ & $\mathrm{X}$ \\
\hline Rain gauge & $\mathrm{X}$ & $\mathrm{X}$ & $\mathrm{X}$ & $\mathrm{X}$ & $\mathrm{X}$ & $\mathrm{X}$ & $\mathrm{X}$ & $\mathrm{X}$ & $\mathrm{X}$ \\
\hline Air pressure & $\mathrm{X}$ & $\mathrm{X}$ & $\mathrm{X}$ & $\mathrm{X}$ & $\mathrm{X}$ & $\mathrm{X}$ & $\mathrm{X}$ & $\mathrm{X}$ & $\mathrm{X}$ \\
\hline Snow pack analyzer & $\mathrm{X}$ & & & $\mathrm{X}$ & & & & & planned \\
\hline Snow height & $\mathrm{X}$ & & & $\mathrm{X}$ & $\mathrm{X}$ & & & & \\
\hline River discharge & planned & & $X(330 \mathrm{~m})$ & & & $X(1300 \mathrm{~m})$ & & & \\
\hline Camera & & & & $\mathrm{X}$ & $\mathrm{X}$ & & & & \\
\hline
\end{tabular}

Table 6. Station installations planned for 2013. All stations will be equipped with standard hydrometeorological sensors and GPS.

\begin{tabular}{|c|c|c|c|c|c|c|c|}
\hline & Maidantal & Kamchik Pass & $\begin{array}{l}\text { Nizhny } \\
\text { Pyandzh }\end{array}$ & Kabul & Golubina & $\begin{array}{l}\text { Kazakhs- } \\
\tan I\end{array}$ & $\begin{array}{l}\text { Kazakhs- } \\
\text { tan II }\end{array}$ \\
\hline Coordinates & $\begin{array}{l}42^{\circ} 00^{\prime} \mathrm{N} \\
70^{\circ} 38^{\prime} \mathrm{E}\end{array}$ & $\begin{array}{l}41^{\circ} 06^{\prime} \mathrm{N}, \\
70^{\circ} 31^{\prime} \mathrm{E}\end{array}$ & $\begin{array}{l}37^{\circ} 12^{\prime} \mathrm{N}, \\
68^{\circ} 36^{\prime} \mathrm{E}\end{array}$ & $\begin{array}{l}34^{\circ} 32^{\prime} \mathrm{N}, \\
69^{\circ} 07^{\prime} \mathrm{E}\end{array}$ & $\begin{array}{l}42^{\circ} 28^{\prime} \mathrm{N} \\
74^{\circ} 29^{\prime} \mathrm{E}\end{array}$ & & \\
\hline River basin & Pskem & Akhangaran & Pyandzh & Kabul & $\mathrm{Chu}$ & & \\
\hline Snow pack analyzer & $\mathrm{X}$ & $\mathrm{X}$ & & & $\mathrm{X}$ & & \\
\hline Snow height & $X$ & $X$ & & & $X$ & & \\
\hline River discharge & $\mathrm{X}$ & & $\mathrm{X}$ & & & & \\
\hline
\end{tabular}

time of melting as well as the estimation of water availability during the melting period.

This station also demonstrates the simple integration of additional non-traditional sensor types or systems to the ROMPS, like camera systems. The station completely handles all connected systems and automatically transfers the data to the SOPAF system for long-term storage and distribution to the users.

\section{Comparison with similar networks}

Scientifically motivated installations of networks of automatic weather stations (AWS) are mainly for process studies and usually focus on small study areas, e.g., on a selected glacier or a selected sub-catchment. They involve a number of sometimes only temporarily installed AWS (e.g., Simoni et al, 2011; Ingelrest et al., 2010). Each individual station may integrate different sensors, may be mounted on different towers, and may have different types of communication facilities. To name a few, examples from the broader region of Central and High Asia are described in, e.g., Maussion et al. (2011) with four AWS on and next to the Zhadang glacier on the Tibetan Plateau, or the SHARE-Everest network of 7 AWS all located in the Khumbu valley, Central Himalaya ${ }^{5}$. Zhang et al. (2012) installed a dense wireless sensor network (WSN) in a small research quadrate of $400 \times 400 \mathrm{~m}^{2}$ in a sub-catchment of the Heihe river in northwestern China. However, though ready-to-use dense WSN have been developed (e.g., SensorScope: Ingelrest et al., 2010) and are of high value for specific research questions, they may not be established at a regional scale and may certainly not cover huge river basins with areas of several hundred-thousand square kilometers.

Opposed to the individually adaptable AWS design, networks being established for operational purposes have requirements with regard to the maintenance, and the standardization of software, the communication, the wiring, and the mechanical elements (e.g., Citterio, 2011, for a network in Greenland). In addition, selection criteria for operational installations focus much more on the question of representativeness for a larger area (i.e., minimizing the number of

\footnotetext{
${ }^{5}$ http://geonetwork.evk2cnr.org:8080/webapp/srv/en/
} 

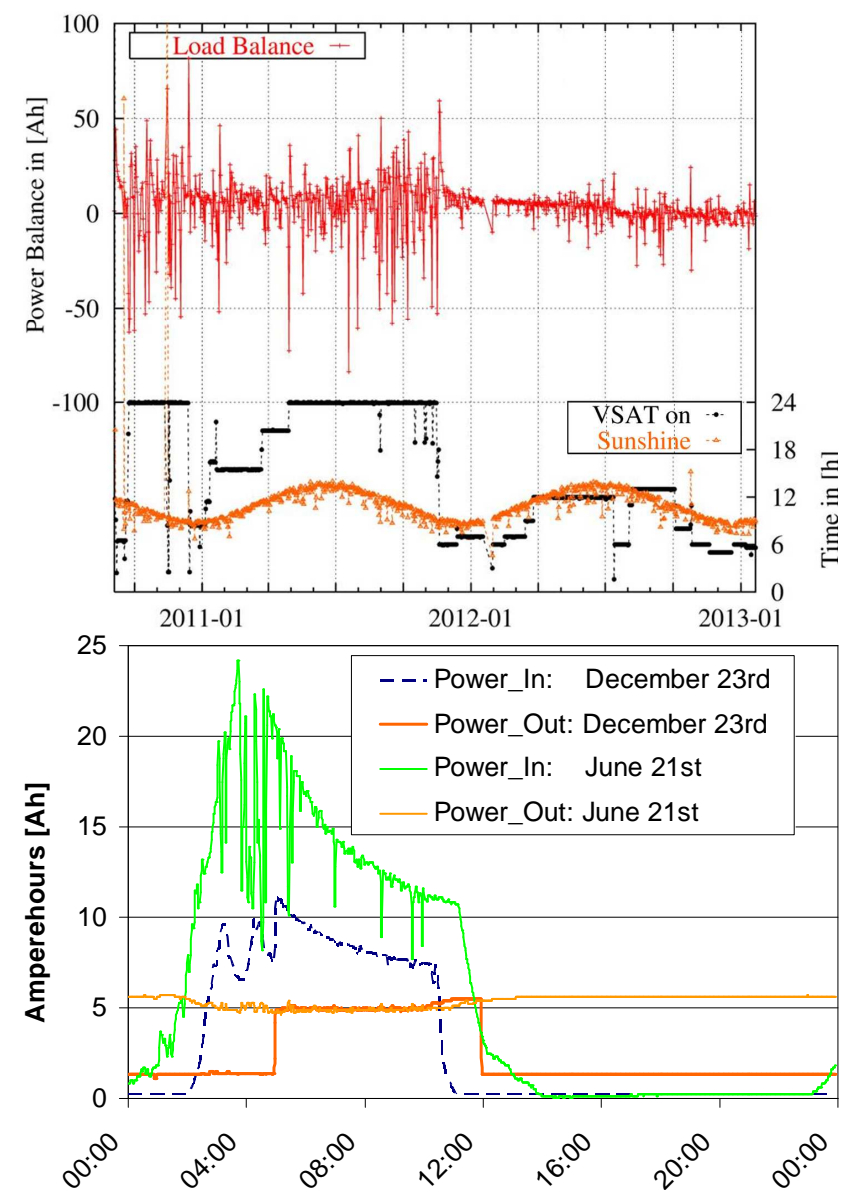

Fig. 8. (a) Power balance for Taragay (red line, left axis) is close to zero. The variability during winter time is related to periods with cloudy skies. The black line indicates VSAT on-times (right axis). The orange line (right axis) shows daily sunshine hours with the distinct annual cycle. (b) Power Charge (green, blue) and Load (orange) at Taragay station for 21 June and 23 December of 2011. The solar input and output is $145 \mathrm{Ah} / 127 \mathrm{Ah}$ and $70 \mathrm{Ah} / 58 \mathrm{Ah}$, respectively. For summer times, VSAT connection is maintained for $24 \mathrm{~h}$, while in inter times, VSAT is available depending on the power level.

necessary installations), the site access for maintenance, and security issues.

As the ROMPS presented in this paper are part of a regional monitoring network which has the task to provide data for operational purposes (e.g., weather forecast, avalanche warning, seasonal runoff forecast), specific user and operational requirements for the standardization of station components, data management, and site selection had to be taken into account. The main considerations for the ROMPS were that (1) the sensor setup is comparable to that of the existing manually operated stations (e.g., measuring wind speed at $U_{10}$ ), (2) the observational data is transmitted in the conventional data format to the existing communication networks of the National Hydrometeorological Services (NHMS), and

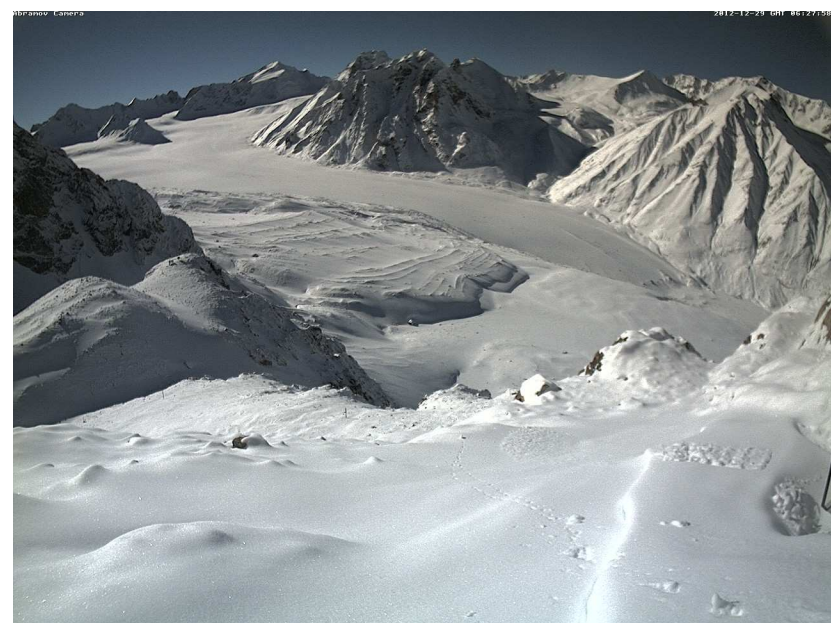

Fig. 9. Picture taken from Abramov station (ABRA) Camera \#2 (29 December 2012).

(3) the sensors fulfill the specifications given in the WMO guidelines (WMO, 2008) or the respective national standards. The most significant difference to other networks is the flexibility and extensibility of the station concept. The ROMPS can be augmented with new sensors and provides opportunities for other low-band to broad-band applications.

\section{Conclusions}

Hydrometeorological monitoring in Central Asia requires an upgrade and extension of the existing ground-based monitoring network and the establishment of a widely accepted information infrastructure to ensure the long-term storage and availability of data and data products as well as an open and unrestricted data access. In the past years, the CAWa/GCO$\mathrm{CA}$ projects contributed to those challenges by establishing nine permanent ROMPS in Central Asian headwater catchments (as of November 2012; the number will be extended), and SOPAF as a data management infrastructure.

The ROMPS of the CAWa/GCO-CA network are designed for long-term monitoring under harsh and varying climate conditions. Even under un-attended operation, the stations show excellent performance in terms of data return rate. Data outages occur only during short station downtimes. The sensing and sampling continues even if no upload to the server is possible (e.g., VSAT downtime in winter due to power restrictions). With the capability for easy hardware and software upgrades and the possibility of extensions with thirdparty equipment there is a wide range of applications for the ROMPS concept.

The stations are operated in different environmental conditions, e.g., in temperature ranges from $-40^{\circ} \mathrm{C}$ to $+50^{\circ} \mathrm{C}$, but thermal chamber tests suggested that the computer and power modules tolerate even higher temperatures. Over the 
three years of operation, the ROMPS have demonstrated that the IP66 grading is sufficient for unsheltered installation.

The System Operation, Processing and Archiving Facility (SOPAF) as the network's central IT-platform serves to collect and integrate information gathered from the network. All data is freely available through two mechanisms. The first is SOS requests (GetCapabilities, GetObservation, DescribeSensor) suitable for integration of SOPAF features into user-specific information systems. The second is a webbased GUI, which allows individual researchers to access information on a predefined way using several output formats. In the future, SOPAF is planned to integrate and re-distribute also information and measurements from external networks. The selected SWE standard and the SOS support the implementation of new phenomena (Phenomenon) or new stations (Procedure).

The drawback of the ROMPS concept is the high initial investment. Thus, the main application field remains in high-altitude areas and un-attended installations. For the future perspective, such a monitoring network has a high potential for the development of Early Warning/Multi-Hazard monitoring applications in a region like Central Asia which is heavily affected by water-related geo-risks, such as land slides, flash floods and glacier lake outburst floods (UNISDR et al., 2009).

In addition to the before mentioned applications, the observational data from the monitoring stations is used as "ground truthing" data for new space-borne monitoring techniques, e.g., in the frame of the CryoSat, EnMap, and GRACE missions (Helmholtz Association, 2012).

Acknowledgements. The presented activities have been generously funded in the frame of the CAWa project (www.cawa-project.net) by the German Federal Foreign Office as part of the "German Water Initiative for Central Asia" (the so-called "Berlin Process", grant AA7090002). This initiative not only provides funding for station installation and operation, but also supports an extensive training programme for technical knowledge transfer about installation, maintenance, and data systems.

Additional funding for the installation and the long-term operation of the monitoring network was and is being provided by the GFZ German Research Centre for Geosciences in the frame of the Global Change Observatory Central Asia (GCO-CA).

The Abramov installation has been also supported by the project "Installation of a monitoring station at Abramov glacier as a joint German-Central Asian research infrastructure" (International Bureau of the BMBF, grant KGZ 10/001).

We appreciate the great support and fruitful cooperation with our colleagues from the National Hydrometeorological Services of Kyrgyzstan, Tajikistan and Uzbekistan, and the Ulugh Beg Observatory of the Astronomical Institute at the Academy of Sciences of the Republic of Uzbekistan. Their generous support and help made the site selections and station installations possible. In addition, we would like to thank the researchers of the University of Fribourg (World Glacier Monitoring Service) for the inspiring cooperation and interesting discussions, in particular Martin Hoelzle for the proposal to integrate an optical camera system for glacier monitoring at Abramov glacier and his team for the support during the installation of the Abramov station. This work is supported through the Capacity Building and Twinning for Climate Observing Systems Program (CATCOS) of the Swiss Agency for Development and Cooperation. We also thank Alexander Merkushkin and his colleagues of UzHydromet (Uzbekistan) for various discussions and the help during the Abramov installation. The main workload for the station preparation and various travels for installations are tirelessly carried out by our colleagues Torsten Queisser, Nico Stolarczuk and Matthias Köppl. At CAIAG the support of A. Shakirov, A. Sharshebaev, F. Yunusov, S. Barkalov, B. Aliev, A. Serenkov, and A. Dudashvili is highly appreciated.

We wish to thank all three anonymous referees for their constructive comments. Most of the comments and suggestions have been incorporated.

The service charges for this open access publication have been covered by a Research Centre of the Helmholtz Association.

Edited by: M. Syrjäsuo

\section{References}

Anderson, P. S.: A method for rescaling humidity sensors at temperatures well below freezing, J. Atmos. Ocean. Technol., 11, 1388-1391, 1994.

Angermann, M., Guenther, M., and Wendlandt, K.: Communication architecture of an early warning system, Nat. Hazards Earth Syst. Sci., 10, 2215-2228, doi:10.5194/nhess-10-2215-2010, 2010.

ARGOS: Argos User's manual, available at: http://www. argos-system.org/files/pmedia/public/r363_9_argos_manual_en. pdf (last access: 8 March 2013), 2011.

Bender, M., Dick, G., Wickert, J., Schmidt, T., Song, S., Gendt, G., Ge, M., and Rothacher, M.: Validation of GPS slant delays using water vapour radiometers and weather models, Meteorologische Z., 17, 807-812, 2008.

Box, J. E., Anderson, P. S., and Van den Broeke, M. R.: Lessons to be learned, in: Automatic weather stations on glaciers - Lessons to be learned and Extended abstracts from the Workshop, edited by: Oerlemans, J. and Tijm-Reijmer, C. H., 28-31 March 2004, Pontresina (Switzerland), 9-28, Institute for Marine and Atmospheric Research, Utrecht University, 2004.

Chard, J. and Bugbee, B.: Electronic measurement of barometric pressure: A Comparison of Omega Model EWSBP-A, Setra Model 276, Setra Model 278, Vaisala Model PTB101B, and Apogee Instruments Model BPS, Uta State University, available at: http://www.usu.edu/cpl/PDF/ BarometricPressureSensors061108.pdf (last access: 18 December 2012), 2006.

Chu, X., Kobialka, T., Durnota, B., and Buyya, R.: Open Sensor Web Architecture: Core Services, in: Proceedings of the 4th International Conference on Intelligent Sensing and Information Processing, Bangalore, India, ICISIP 2006, IEEE Press, Piscataway, New Jersey, USA, ISB 1-244-611-0, 98-103, available at: 
ttp://www.gridbus.org/papers/ICISIP2006-SensorWeb.pdf (last access: 20 December 2010), 15-18 December, 2006.

Citterio, M.: Design and performance of the GEUS AWS, in: Workshop on the use of automatic measuring systems on glaciers - Extended abstracts and recommendations of the IASC Workshop, edited by: Tijm-Reijmer, C. H. and Oerlemans, J., 23-26 March 2011, Pontresina (Switzerland), 22-26, Institute for Marine and Atmospheric Research, Utrecht University, 2011.

Corripio, J.: Snow surface albedo estimation using terrestrial photography, Int. J. Remote Sens., 25, 5705-5729, 2004.

Dow, J. M., Neilan, R. E., and Rizos, C.: The International GNSS Service in a changing landscape of Global Navigation Satellite Systems, J. Geod., 83, 191-198, doi:10.1007/s00190-008-03003, 2009.

ECMWF: CREX User's Guide and Reference, http: //www.wmo.int/pages/prog/gcos/documents/gruanmanuals/ ECMWF/crex_user_guide.pdf (last access: 8 March 2013), 2006. EUMETSAT: TD 16 - Meteosat Data Collection and Retransmission Service, available at:http://www.eumetsat.int/idcplg?

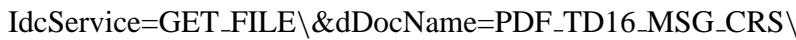
$\&$ RevisionSelectionMethod=LatestReleased (last access: 20 December 2012), 2009.

Finaev, A.: Review of hydrometeorological observations in Tajikistan for the period of 1990-2005, in: Assessment of Snow, Glacier and Water Resources in Asia, edited by: Braun, L. N., Hagg, W., Severskiy, I. V., and Young, G., Selected papers from the Workshop in Almaty, Kazakhstan, 2006, UNESCO-IHP and German IHP/HWRP National Committee, IHP/HWRP-Berichte 8, 55-64, Koblenz, 2009.

Fleischer, J., Häner, R., Herrnkind, S., Kloth, A., Kriegel, U., Schwarting, H., and Wächter, J.: An integration platform for heterogeneous sensor systems in GITEWS - Tsunami Service Bus, Nat. Hazards Earth Syst. Sci., 10, 1239-1252, doi:10.5194/nhess-10-1239-2010, 2010.

Gorodetskaya, I. V., van Lipzig, N. P. M., Boot, W., Reijmer, C., and van den Broeke, M. R.: AWS measurements at the Belgian Antarctic station Princess Elisabeth, in Dronning Maud Land, for precipitation and surface mass balance studies, in: Workshop on the use of automatic measuring systems on glaciers - Extended abstracts and recommendations of the IASC Workshop, edited by: Tijm-Reijmer, C. H. and Oerlemans, J., 23-26 March 2011, Pontresina (Switzerland), 40-44, Institute for Marine and Atmospheric Research, Utrecht University, 2011.

Gurtner, W. and Estey, L.: RINEX - The Receiver Independent Exchange Format, Version 3.00, University of Berne, 2007.

Hanka, W., Heinloo, A., and Jäckel, K.-H.: Networked Seismographs: GEOFON Real-Time data Distribution, ORFEUS Electronic Newsletter, 2, 3, available at: http://www.orfeus-eu. org/Organization/Newsletter/vol2no3/geofon.html (last access: 8 March 2013), 2000.

Helmholtz Association: Helmholtz Roadmap for Research Infrastructures, available at: http://www.helmholtz.de/fileadmin/user_ upload/publikationen/pdf/11_Helmholtz_Roadmap_EN_WEB. pdf (last access: 20 December 2012), 2012.

Herring, T. A., King, R. W., and McClusky, S. C.: Documentation for the GAMIT/GLOBK GPS processing software release 10.3, Mass. Inst. of Technol., Cambridge, 2009.

Huss, M., Sold, L., Hoelzle, M., Stokvis, M., Salzmann, N., Daniel Farinotti, D., and Zemp, M.: Towards remote monitoring of sub-seasonal glacier mass balance, Ann. Glaciol., 56, 85-93, doi:10.3189/2013AoG63A427, 2012.

Huwald, H., Higgins, C. W., Boldi, M., Bou-Zeid, E., Lehning, M., and Parlange, M. B.: Albedo effect on radiative errors in air temperature measurements, Water Resour. Res., 45, W08431, doi:10.1029/2008WR007600, 2009.

Ingelrest, F., Barrenetxea, G., Schaefer, G., Vetterli, M., Couach, O., and Parlange, M.: SensorScope: Application-specific sensor network for environmental monitoring, ACM T. Sensor Network., 6, 1-32, doi:10.1145/1689239.1689247, 2010.

Inmarsat Global Limited: BGAN Overview Brochure, available at: http://www.inmarsat.com/cs/groups/inmarsat/documents/assets/ 018710.pdf (last access: 20 December 2012), 2009.

Iridium Communications Inc.: Iridium 9522B, L-Band Satellite Transceiver, available at: http://www.iridium.com/ DownloadAttachment.aspx?attachmentID=564 (last access: 20 December 2012), 2010.

Itibayev, Z.: Report of the State Agency for Hydrometeorology at the Ministry for Emergency Situations of the Kyrgyz Republic (Kyrgyz Hydromet), Regional Workshop "Improving Weather, Climate and Hydrological Service Delivery, and Reducing Vulnerability to Disasters in Central Asia and Caucasus", Tashkent, (available at: http://siteresources.worldbank.org/INTUZBEKISTAN/ Resources/294087-1246601504640/Day2_s3_f8_rus.pdf) (last access: 20 December 2012), 2009 (in Russian).

Jeanicke, J., Mayer, C., Scharrer, K., Münzer, U., and Gudmundsson, A.: The use of remote-sensing data for mass-balance studies at Myrdalsjökull ice cap, Iceland, J. Glaciol., 52, 565-573, 2006.

Kayumov, A., Makhmadaliev, B., and Novikov, V.: Tajikistan. The first national communication of the Republic of Tajikistan to the United Nations Framework Convention on Climate Change, Addendum. Phase 2: Capacity building in priority areas, 2002.

Kloth, A.: Concept, Design and Implementation of Reliable and Autonomous Systems, Master Thesis, University of Potsdam, Institute for Computer Science Operating Systems and Distributed Systems, 2008.

Maussion, F., Wei, Y., Huintjes, E., Pieczonka, T., Scherer, D., Yao, T., Kang, S., Bolch, T., Buchroithner, M., and Schneider, C.: Glaciological field studies at Zhadang Glacier (5500-6095 m), Tibetan Plateau, in: Workshop on the use of automatic measuring systems on glaciers - Extended abstracts and recommendations of the IASC Workshop, edited by: Tijm-Reijmer, C. H. and Oerlemans, J., 23-26 March 2011, Pontresina (Switzerland), 62-68, Institute for Marine and Atmospheric Research, Utrecht University, 2011.

Mittelbach, H., Lehner, I., and Seneviratne, S. I.: Comparison of four soil moisture sensor types under field conditions in Switzerland, J. Hydrol., 430-431, 39-49, doi:10.1016/j.jhydrol.2012.01.041, 2012.

O\&M: Geographic Information: Observations and Measurements, OGC Abstract Specification Topic 20, Version 2.0.0, ref. OGC 10-004r3 and ISO 19156, available at: http://portal. opengeospatial.org/files/?artifact_id=41579 (last access: $20 \mathrm{De}$ cember 2012), 2010.

OGC: OpenGIS: OpenGIS ${ }^{\circledR}$ Standards, available at: http://www. opengeospatial.org/standards (last access 20.12.2012), 2010.

Pertziger, F. I.: Abramov Glacier Data Reference Book: Climate, Runoff, Mass Balance, 279 p., Technical University Munich, 
Tashkent/Munich, 1996

Rabatel, A., Dedieu, J.-P., and Vincent, C.: Using remote-sensing data to determine equilibrium-line altitude and mass-balance time series: validation on three French glaciers, 1994-2002, J. Glaciol., 51, 539-546, 2005.

Rabatel, A., Dedieu, J.-P., Thibert, E., Letréguilly, A., and Vincent, C.: 25 years (1981-2005) of equilibrium-line altitude and mass-balance reconstruction on Glacier Blanc, French Alps, using remote-sensing methods and meteorological data, J. Glaciol., 54, 307-314, doi:10.3189/002214308784886063, 2008.

Reijmer, C. H. , van den Broeke, M. R., and Boot, W.: Measuring humidity at temperatures well below zero, in: Automatic weather stations on glaciers - Lessons to be learned and Extended abstracts from the Workshop, edited by: Oerlemans, J. and TijmReijmer, C. H., 28-31 March 2004, Pontresina (Switzerland), 88-92, Institute for Marine and Atmospheric Research, Utrecht University, 2004.

Schilling, D. L.: Meteor burst communications - Theory and practice, John Wiley \& Sons Inc., New York, 480 p., 1993.

Schöne, T., Illigner, J., Manurung, P., Subarya, C., Khafid, Zech, C., and Galas, R.: GPS-controlled tide gauges in Indonesia - a German contribution to Indonesia's Tsunami Early Warning System, Nat. Hazards Earth Syst. Sci., 11, 731-740, doi:10.5194/nhess11-731-2011, 2011.

Simoni, S., Padoan, S., Nadeau, D. F., Diebold, M., Porporato, A., Barrenetxea, G., Ingelrest, F., Vetterli, M., and Parlange, M. B.: Hydrologic response of an alpine watershed: Application of a meteorological wireless sensor network to understand streamflow generation, Water Resour. Res., 47, W10524, doi:10.1029/2011WR010730, 2011.

Sommer: Sommer Mess-Systemtechnik: RQ24 - Non-contact measurement of discharge, Product information, available at: http://www.sommer.at/fileadmin/template/PDF/mySommer/ RQ-24/Productinfo_RQ24_Vxx.xx.rxx_V009_ENG_www.pdf) (last access: 20 December 2012), 2008.
Sommer: Sommer Mess-Systemtechnik: Snow Pack Analyser (SPA) for snow water equivalent (SWE) and liquid water content, Document release: V1.0.0, (available at: http://www.sommer.at/fileadmin/template/PDF/mySommer/ SPA/Paper_SPA_V001_ENG.pdf) (last access 20.12.2012), 2009.

Sorg, A., Bolch, T., Stoffel, M., Solomina, O., and Beniston, M.: Climate change impacts on glaciers and runoff in Tien Shan (Central Asia), Nat. Clim. Change, 2, 725-731, doi:10.1038/nclimate1592, 2012.

SOS: Sensor Observation Service, Version 1.0, ref. OGC 06-009r6, available at: http://portal.opengeospatial.org/files/ ?artifactid=26667 (last access: 20 December 2012), 2007.

UNISDR: World Bank, and World Meteorological Organization: Central Asia and Caucasus disaster risk management initiative (CAC DRMI), Risk assessment for Central Asia and Caucasus Desk study review, available at: http://www.preventionweb.net/ files/11641_CentralAsiaCaucasusDRManagementInit.pdf (last access: 20 December 2012), 2009.

WMO: Guide to Meteorological Instruments and Methods of Observation, WMO-No. 8, available at: https://www.google. com/url?q=http:/www.wmo.int/pages/prog/gcos/documents/ gruanmanuals/CIMO/CIMO_Guide-7th_Edition-2008.pdf) (last access: 20 December 2012), 2008.

World Bank: Improving weather, climate and hydrological services delivery in Central Asia (Kyrgyz Republic, Republic of Tajikistan, and Turkmenistan), Report prepared in the frame of the technical assistance project "An action plan for improving weather and climate service delivery in high-risk, low-income countries in Central Asia", World Bank Russia Country Office, Moscow, 2009.

Zhang, Y., Luo, L., Huo, J., and Zhu, W.: An Eco-hydrology wireless sensor demonstration network in high-altitude and alpine environment in the Heihe River Basin of China, Lect. Notes Comput. Sc., 4, 138-146, doi:10.4236/wsn.2012.45020, 2012. 